\title{
1. What were the causes of the Great Recession? The mainstream approach vs. the monetary interpretation*
}

\section{Tim Congdon}

What were the causes of the Great Recession of late 2008 and 2009? The current chapter distinguishes and contrasts two ways of thinking about this question. The first, which has dominated official discussion and media coverage, can be seen as "the mainstream approach"; the second, which has had less attention, may be called "the monetary interpretation". ${ }^{1}$ The main claim here is that the mainstream approach is inadequate and unconvincing, while the evidence is consistent with an analysis in which the quantity of money plays a central causal role. As the Great Recession was international in scope, one difficulty is to specify the particular jurisdiction to which the discussion relates. An Appendix will review the monetary experience of the key nations, but the analysis in the main text will appeal mostly to statistics from the USA. An advantage of the monetary interpretation is that during the crucial period it fits data for all the key nations, with the exception of Japan. The first section describes and interrogates the mainstream approach. It tries to do so fairly, although the author's views are hardly disguised. The second section expounds the monetary interpretation. It applies the monetary theory of the determination of national income and wealth to both a narrative of events and key statistical series. A short conclusion contends that policy-makers and their economic advisers, as well as the economics profession at large, ought to pay more attention to the work that the quantity of money plays in motivating the business cycle, including such extreme events as the Great Recession. 
Explanations of the Great Recession have been diverse. Andrew Lo's review article of 21 volumes on the crisis in the 2012 Journal of Economic Literature opined that, "no single account of this vast and complicated calamity is sufficient to describe it". It separated the books into the academic and the journalistic, and said that the academic were the more interested "in identifying underlying causes", but then remarked that the academic contributions "seem to exhibit the most heterogeneity". A problem with such heterogeneity was that it risked failing to provide a single cut-and-dried set of policy prescriptions. Nevertheless, in the aftermath of the crisis policy-makers seemed to share enough of a consensus about causation that they could agree on an agenda of remediation. ${ }^{3}$ In that agenda banks were in future to operate with higher capital-to-asset ratios, more substantial buffers of liquid assets to total assets and less wholesale funding, and they were to be subjected to tighter regulatory scrutiny. The near unanimity on the correct policy response argues that officialdom had a widely agreed interpretation of the crisis, even if this interpretation might have been better elucidated.

The sequence of events may have prompted the thinking behind one element in the mainstream discussion. By common consent, the crisis began with the freezing of the international inter-bank market in August 2007. Financial organizations that had been reliant on inter-bank funding of their assets in earlier years suddenly found themselves unable to access new lines and often had trouble rolling over existing facilities. A plausible view was that the interruption of inter-bank credit was due to mutual distrust within the banking industry, as the better-placed institutions worried about weaker counterparties' asset quality and capital adequacy. The crisis was therefore about banks' lack of solvency and indeed, if the worst came to the worst, about outright insolvency.

The emphasis on solvency seemed to make sense in autumn 2008. On 15 September 2008 Lehman Brothers defaulted in the world's largest ever bankruptcy, with losses to its creditors that might theoretically reach $\$ 600$ billion. By implication, policy-makers were right to demand that in future banks operate with higher capital ratios, stronger liquidity buffers and so on. Also by implication, the severe global downturn in late 2008 and early 2009 was due to lack of confidence in a broken financial system. More generally, the Great Recession was caused by the follies of free market capitalism. The tightening of regulations from 2008 was therefore viewed as necessary to bring capitalism under control and to force banks to shrink their businesses.

Mainstream thinking has appeared in many places, if with a variety 
of emphases. In his massively influential column in the New York Times, Paul Krugman has been a leading expositor, and he is cited below in the present chapter and several times elsewhere in this book. A salient strand has been that financial market practitioners took excessive risk relative to capital, with their actions motivated by inordinate "animal spirits". This strand has been highlighted in the work of Robert Shiller, one of the Nobel economics laureates in 2013 and a well-known spokesman for "behavioural finance". Shiller co-authored with George Akerlof, another Nobel prizewinner, a 2009 book actually entitled Animal Spirits, which drew on "an emerging field called behaviour economics" and averred that their investigation "describes how the economy really works". ${ }^{4}$ Similar emphases were found in Alan Greenspan's 2013 book The Map and the Territory. The first chapter was called 'Animal Spirits' and had a section on "behavioural economics". In the next two chapters Greenspan focused on the crisis period and at one point mentioned "herd behaviour" in the context of asset price bubbles. The reference clearly invited the interpretation that fluctuations in asset prices were (and always are) to be attributed to the changing moods of investors. Later, Greenspan posited that, "market liquidity is largely a function of the degree of risk aversion of investors, clearly the dominant animal spirit that drives financial markets". 5

The buoyant asset prices of the 2005-07 mini-boom period immediately ahead of the crisis are seen in the mainstream approach as the result of contagious euphoria, in line with the animal spirits thesis. Asset price movements become a function of changing human psychology instead of being related to other macroeconomic variables. Akerlof and Shiller did in fact offer sceptical words in their 2009 book about any substantive theory of asset price determination. To quote, "No one has ever made rational sense of the wild gyrations in financial prices, such as stock prices." "However, mainstream authors often argue that the big declines in spending in late 2008 and 2009 were explicable in balance-sheet terms. ${ }^{7}$ As Figure 1.1 shows, in the USA the decline in net worth was concentrated in the six quarters to the first quarter of 2009 and amounted to over one year of personal disposable income (PDI). The slide in the stock market in 2008 and, above all, the crash in residential real estate from 2006 to 2009 tend to be emphasized in mainstream analyses, while the fall in asset prices is contrasted with the heavy burden of debt incurred in the good years before 2007.

Informal comments on the growth of debt often have a moral tinge. ${ }^{8}$ Worries about debt may be stated more rigorously in terms of the concept of "leverage", with the sustainability of debt assessed relative to servicing ability or collateral. Greenspan, like other observers, was particularly exercised in The Map and the Territory about the allegedly "extraordinary leverage ... 


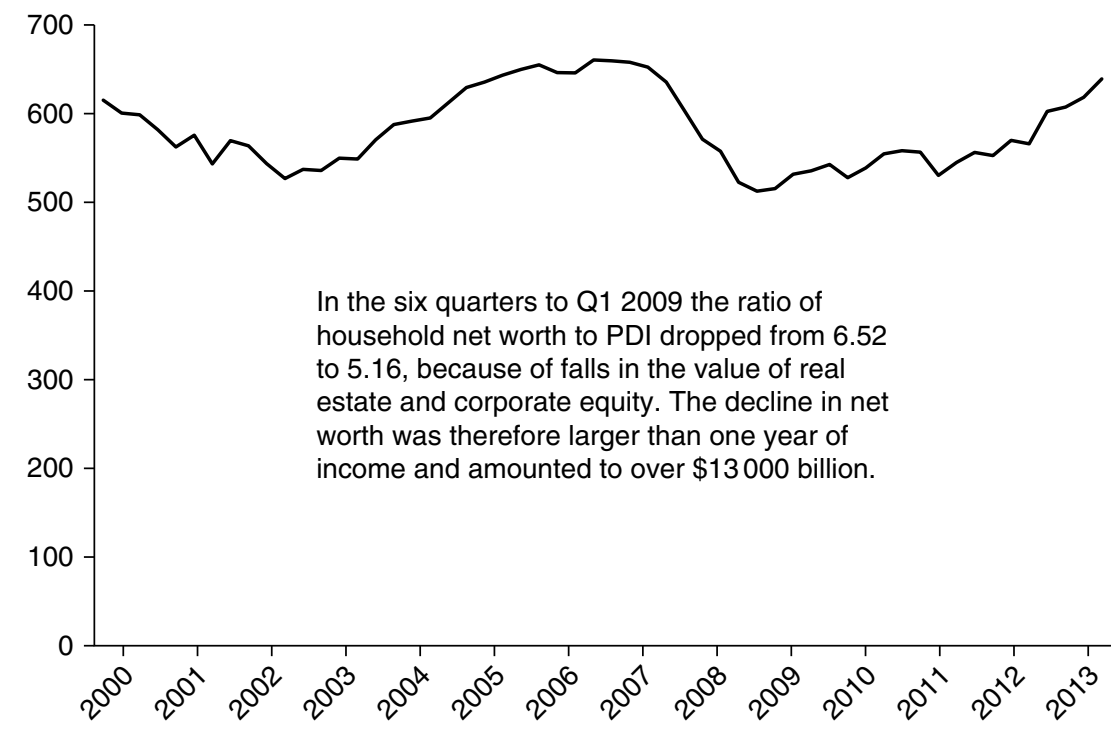

Source: Data are quarterly and are from the Federal Reserve.

Figure 1.1 Household net worth as a percentage of personal disposable income in the USA

taken on by US investment banks", citing balance sheet totals that might be "twenty-five to thirty times tangible capital". ${ }^{9}$ But excessive leverage is also said to have been a characteristic of the entire American banking system, including the commercial banks, ahead of the crisis period..$^{10}$

Excessive debt and risk-taking could of course be found in both the banking sector and among non-bank private sector agents. However, much mainstream commentary on the Great Recession regards banks' balancesheet patterns as having particular macroeconomic significance, in line with the emphasis placed on the special nature of bank credit in influential articles on "the credit channel" by Robert Bernanke, Alan Blinder and Mark Gertler. ${ }^{11}$ The mainstream interpretation of the Great Recession does give banks a starring role in the drama, even if they are its anti-heroes. This is an important merit in view of the unrealistic neglect of banks in, for example, the three-equation New Keynesianism that was fashionable among central bank economists in the years preceding the crisis. ${ }^{12}$ The emphasis in the mainstream discussions is on the assets side of banks' balance sheets as having the vital macroeconomic effects. Little or no reference is made to the deposits on the liabilities side, which are the principal component of the quantity of money as usually defined. 
Proponents of the mainstream analysis, with their belief in the specialness of banks' assets, concluded in late 2008 and 2009 that a resumed flow of bank credit was a precondition of recovery. This thought remained influential throughout the crisis period and afterwards. According to the Federal Reserve website as updated on 19 July 2013, the Federal Reserve Board had decided that month to implement the Basel III package of bank regulation. The package was justified, in its view, on the grounds that, "banks [must] maintain strong capital positions that will enable them to continue lending to creditworthy households and businesses even after unforeseen losses and during economic downturns".

Of course the extension of credit involves risks, against which banks must in the ordinary course of business maintain a protective layer of capital. So, again to quote from the Fed website, the adoption of Basel III would increase "both the quantity and the quality of capital held by US banking organizations". The supposed beneficence of high bank capital levels appears to be agreed by the overwhelming majority of experts and commentators on the crisis. In late 2008 Paul Krugman praised UK policy-makers, notably the Prime Minister Gordon Brown, in his New York Times column because their bank-recapitalization plan was judged to be superior to the US Treasury's scheme to purchase so-called "toxic securities" from the banks. ${ }^{13}$ In his 2013 book After the Music Stopped, Alan Blinder - one of Bernanke's co-authors and a former vice-chairman of the Federal Reserve Board - opined, "The crisis exposed numerous flaws in the nation's regulatory system. One painfully obvious one was that banks and other financial institutions had been allowed to operate with too much leverage, that is, with too little capital." 14 To summarize, the mainstream interpretation

- sees bank insolvency, actual or potential, as the main symptom of an unsatisfactory financial system and an important cause of the wider crisis;

- it indicts the bankers, understood to be greedy and driven by animal spirits, as particularly to blame for the macroeconomic setbacks of the Great Recession;

- it praises the tightening of bank regulation and bank recapitalizations of autumn 2008 as the key feature of an appropriate policy response; and

- it upbraids the financial system in Western liberal democracies as inherently unstable and dysfunctional, and as an entrenched weakness of modern capitalism. ${ }^{15}$

But is the mainstream interpretation persuasive? One problem is the thinness of its conceptual basis, since an appeal to "lack of confidence" 
(or "animal spirits") as a determinant of aggregate demand is difficult to fit in a robust theory of national expenditure and output. How is the notion of "confidence" to be quantified and then tested with data? If an account of events invokes a theory of some sort in order to have at least a semblance of scientific status, it needs to be applicable in the same way with the same variables on a large number of occasions. In their Animal Spirits book Akerlof and Shiller recalled the multiplier theory of national income determination in Keynes' General Theory, but downplayed Hicks' classic statement of that theory and advanced claims for their own notion of "a confidence multiplier" ${ }^{16}$ It may well be true that people increased their spending in 2007 because they were "more confident" and spent less in 2009 because they were "more worried". But does that take us very far?

Further, with the passage of time the focus on banks' solvency, and on their leverage and capital positions, has become questionable. A common refrain was that confidence collapsed because banks were "bust". But how many banks were bust, meaning that they had exhausted all their equity capital, and so were unable to meet obligations to bondholders, depositors and other creditors? In the American context a key distinction is between commercial and investment banks. According to the usual understandings, commercial banks extend loans, take deposits, and provide depositors with money transmission and cash settlement services. By contrast, investment banks are in the very different business of trading securities with customers and underwriting securities issues by corporate customers; they are not usually involved in money transmission or cheque clearing, and fund their securities holdings not from retail depositors but from wholesale sources, including inter-bank lines. In the USA commercial banks have long been supervised by the Federal Reserve, whereas investment banks were traditionally regulated by the Securities and Exchange Commission. Admittedly, some overlap exists between the two kinds of bank, partly because over the last 20 years the emergence of bank holding companies (with both commercial and investment banking businesses answering to the same group of shareholders) has muddied the picture.

The Federal Reserve has long compiled data on the condition of the commercial banks that come under its wing. The two main issues raised by the mainstream interpretation are:

1. the level of banks' capital/asset ratios at different times, particularly the level today and in the recent past compared with historical norms;

2. the vulnerability of banks' capital to actual or expected losses, and more specifically the extent to which banks' capital at the start of the Great Recession was eliminated by losses during it. 


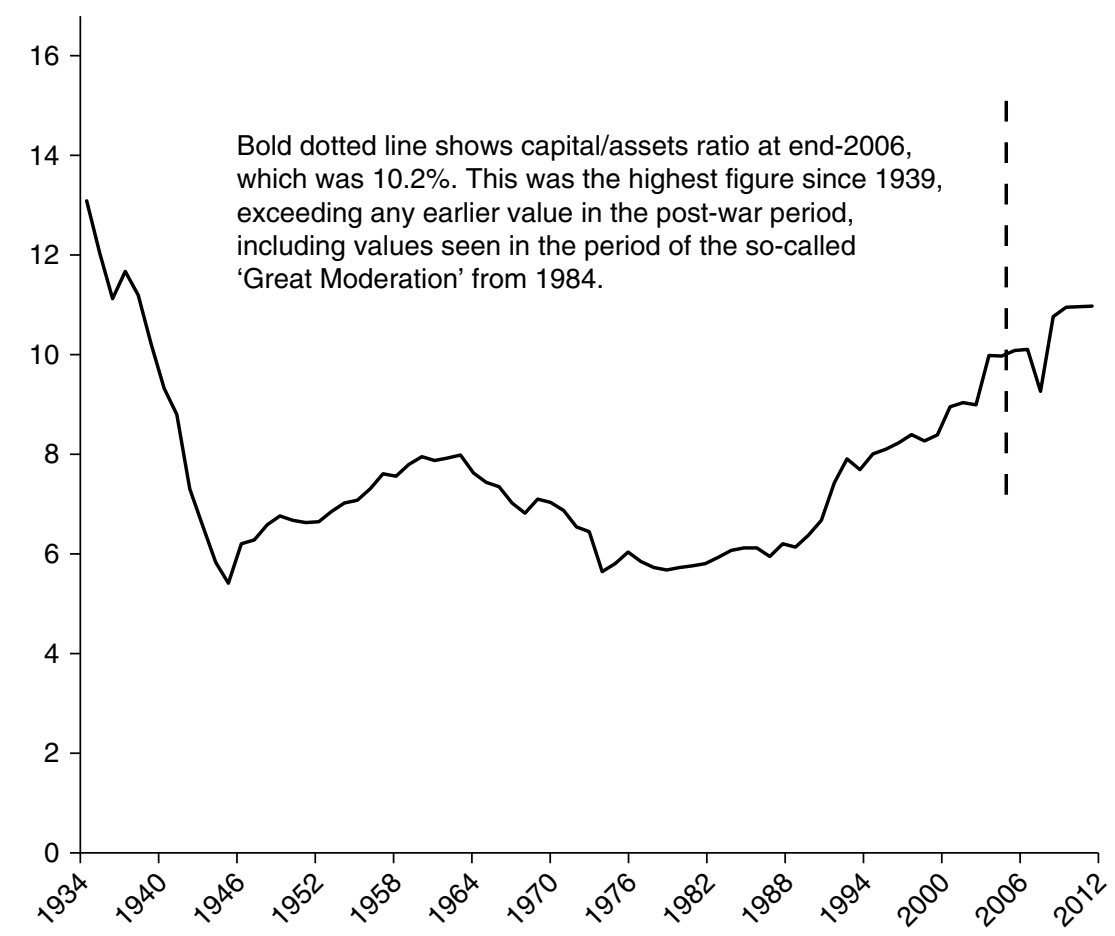

Source: Data are from the Federal Deposit Insurance Corporation.

Figure 1.2 Equity capital to total assets ratio of US commercial banks, 1934-2012 (showing ratio, \%, at year-end)

The relevant numbers are readily available from well-known sources. On the first issue, two graphs present the most important information. The first (Figure 1.2) covers the period from the foundation of the Federal Deposit Insurance Corporation to 2012 and uses the FDIC data for yearends; the second (Figure 1.3) relates to the Great Recession itself, taken for these purposes to begin in 2007 , with the data being quarterly and sourced from the Federal Reserve. The first graph shows that US banks' equity/ capital ratio just before the Great Recession, at end-2006, was the highest it had been since 1939. The average value of the ratio in the 61 post-war years (that is, 1946 to 2006 inclusive) had been 7.2 per cent. The end-2006 value was over 40 per cent higher than this, at 10.2 per cent. The second graph shows that US banks' capital was resilient during the crisis period. A dip in the capital/asset ratio did occur during 2008, with the figure for the fourth quarter of 2008 at 9.4 per cent being 0.8 per cent of assets lower 


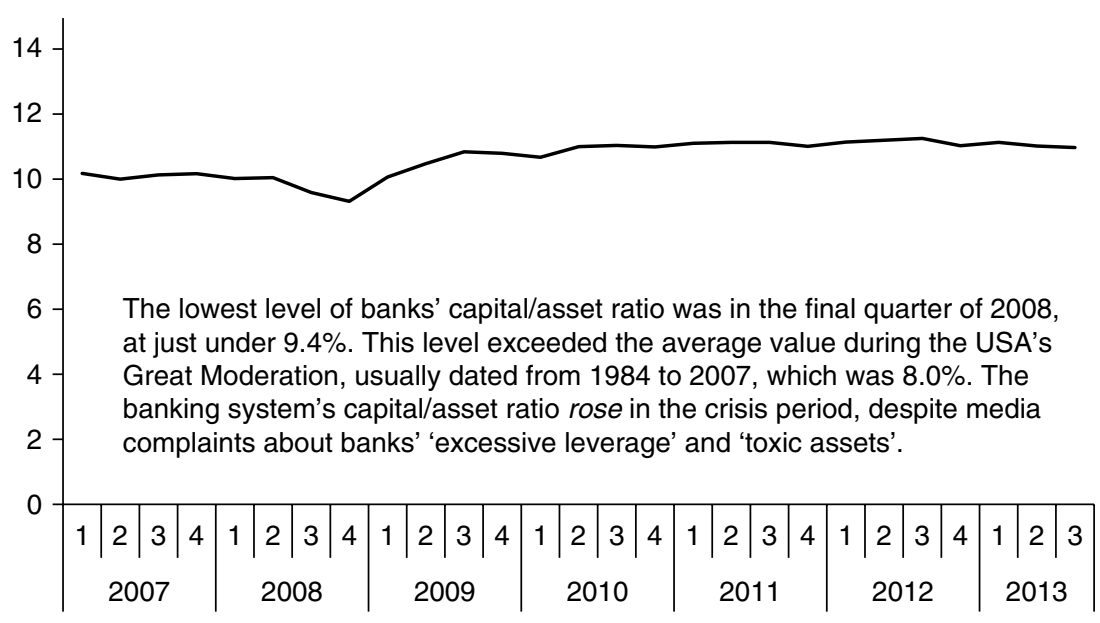

Source: Data are from Federal Reserve.

Figure 1.3 Equity capital to total assets ratio of US commercial banks in the Great Recession and after (showing ratio, \%, quarterly)

than a year earlier. However, this left the end-2008 value still at over 90 per cent of that a year earlier, which - to repeat - was the highest for more than 65 years.

What about the second issue, the vulnerability of banks' capital to loss? The last paragraph has demonstrated that during the Great Recession the American commercial banking system was at no point near to insolvency. However, this apparent robustness may have been due to massive capitalraising after heavy losses, which would hardly be reassuring. Data are needed also for the loss experience of the US banks during these years. Again the Federal Reserve compiles the necessary data. A key metric, the per cent return on equity, is shown in Figure 1.4, with the values being both as actually reported for each quarter and as a four-quarter moving average of these reported numbers.

The main point here is that the US commercial banking system, taken in the aggregate, had only one quarter of loss in the Great Recession. This was in the final quarter of 2009 and amounted to a trivial 1.0 per cent of equity. As Figure 1.4 shows, the fourth-quarter 2009 loss was less than that in the second quarter of 1987 (6.0 per cent of equity), when the New York money centre banks wrote off much of their Third World debt. However, the quarterly values may be misleading, in that the Third World debt write-offs were concentrated in a few quarters of 1987 and the sharpness 


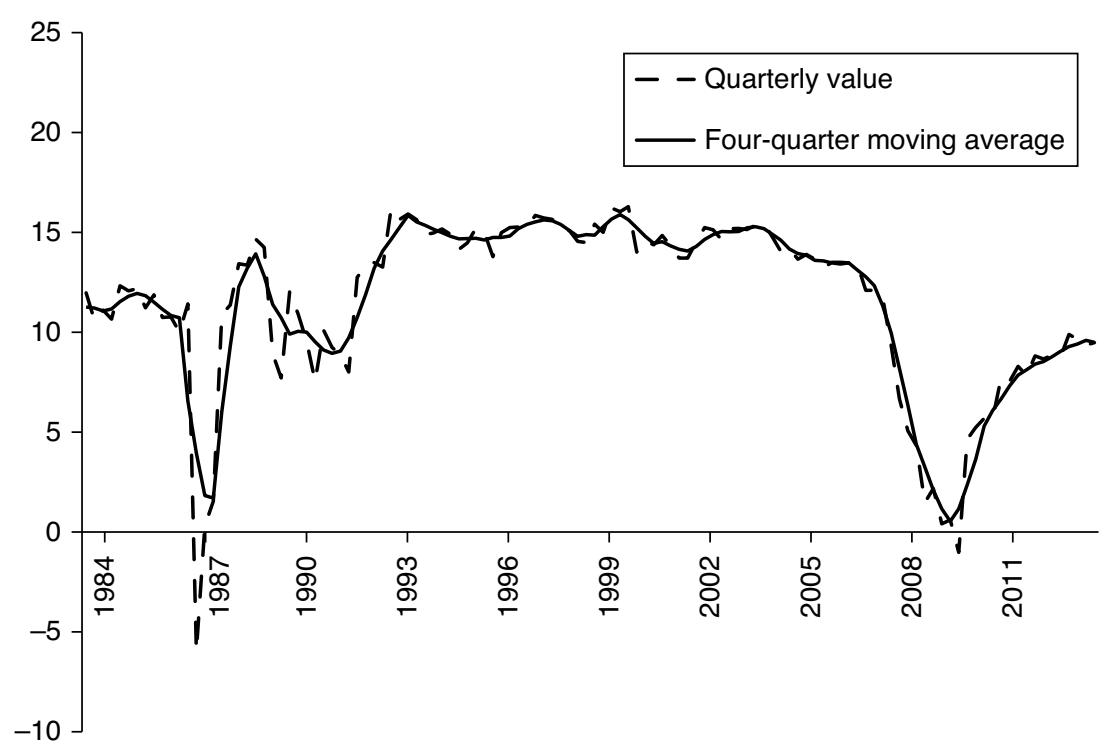

Source: Federal Reserve data.

Figure 1.4 Return on equity in US commercial banking, 1984-2013 (\%, quarterly)

of the dip indicated by the line in the chart is deceptive. The line for the four-quarter moving average suggests that American banks had a rougher time in the Great Recession than in the 1980s, with a longer period of low profitability, which is in accordance with the media stereotype. However, outright losses would need to have been recorded before being able to accuse the banks that they might "go bust" and hence imperil the safety of deposits. It is evident that this was not so. On this basis, American banks did not in the aggregate incur a dangerous level of losses during the Great Recession. ${ }^{17}$

The USA, frequently identified as the epicentre of the problems, had a banking system that was solvent at the start of the crisis, remained solvent during the worst of the turmoil and still is solvent today. Indeed, the much-repeated assertion that "leverage" was exceptional in the pre-crisis period is false, at least as far as the American commercial banking industry is concerned. (Note that the Lo article in the 2012 Journal of Economic Literature argued that even the investment banks had similar leverage in 1998 and 2006. ${ }^{18}$ ) As widely noted at the time, in the early 1980s the equity capital to asset ratios at the New York money centre banks were mostly 
under 5 per cent. ${ }^{19}$ In the decade to end-1997 the ratio of US commercial banks' equity to assets averaged 7.3 per cent and in the following decade it averaged 9.3 per cent. Both these figures were therefore well above the level maintained during the Third World debt problems 30 years earlier.

Just before the Lehman debacle itself the ratio was 10.1 per cent, and nowadays, because of the regulatory pressure from officialdom, the ratio is higher still. (See Chapters 5 to 7 for more on the changes in banks' capital to assets ratios since 2008.) Roughly speaking, the average American bank now has an equity capital to assets buffer which is three times thicker than that at the New York money centre banks 30 years ago. If the American people cut their spending in 2009 because they thought their banks were bust, why did they raise their expenditure in 1983 and 1984 at the start of the Reagan boom when the data show that their banks had a higher risk of failure?

No doubt, more discussion is needed before the current attempt to refute the mainstream interpretation is altogether convincing. Although the American banking system in the aggregate was robust during the Great Recession, some individual institutions did have large losses and either "went bust" or were on the borderline between insolvency and solvency. ${ }^{20}$ However, these losses were never sizeable relative to the capital of the banking system as a whole and no new government money was needed to shore up the Federal Deposit Insurance Corporation. In her book Bull by the Horns, Sheila Bair, chairman of the FDIC, noted Warren Buffett's view that in early 2009 the American banking system was essentially sound. In her words, reporting a conversation between them, "Most of the banking institutions [then being subject to stress tests] were relatively healthy, he said, and in any event, fourteen of the nineteen banks being stress tested, could easily be resolved under the FDIC's normal processes if they got into trouble."

Remarkably, she then acknowledged that "Buffett was right". ${ }^{21}$ Bair also said that the various financial interventions (that is, guarantees and loans, as well as capital subscriptions) by the US government and its agencies during the Great Recession had ultimately proved profitable, although expressing dismay at a system which envisages picking "winners and losers with taxpayer money". ${ }^{22}$ (But the FDIC has received no grants or capital injections from the US government since its creation in 1933 and in that sense the reference to "taxpayer money" is not correct. The FDIC's solvency is protected by insurance premiums received from shareholder-owned commercial banks. To quote from a note 'Who is the FDIC?', published in 2008 on its 75th anniversary and still available [September 2016] on its website, "The FDIC receives no Congressional appropriations." ${ }^{23}$ ) 
The financial outcome of the government interventions is crucial. In the 1980s and 1990s the US taxpayer lost substantial sums, usually estimated at about $\$ 150$ billion, from government involvement in the savings and loans crisis. (Macroeconomic trends in the early 1980s undermined the financial viability of hundreds of savings and loans associations. The "S\&L's" had long-term mortgage assets which returned interest income on fixed-rate terms. They could not cover their funding costs, given the surge in interest rates. $)^{24}$ But the resolution of the savings and loans crisis had been accompanied by far less trauma than seen in the 2008-10 period. Indeed, the losses to the American taxpayer from the resolution of the savings and loans associations coincided with the benign years of the Great Moderation. The compatibility of such losses with macroeconomic stability again casts doubt on the claim that potential commercial bank insolvency, due to excessive leverage and inadequate capital, was the central problem for the American economy in the Great Recession.

Let it be admitted that the American investment banks had far more trouble in the crisis years than the much larger commercial banking system, particularly in the egregious case of Lehman Brothers Holdings Inc. Lehman did indeed have a large deficiency in its North American operations when it was wound up. But an obvious puzzle is to explain how losses of $\$ 150$ billion or so from one business were capable of subverting the entire American economy, with an annual output in the relevant period

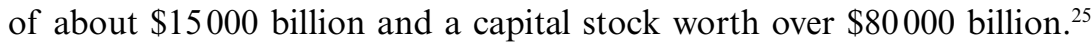
Relative to fluctuations in the value of the USA's net wealth, because of changes in the general level of asset prices, the Lehman deficiency was miniscule. Nevertheless, in a curious comment in a 2014 book on What Have We Learned? Macroeconomic Policy after the Crisis, Akerlof implied that the Lehman deficiency was indeed of great importance, as policy-makers had astutely put "a finger in the dyke" to stop the dam of insolvency bursting. ${ }^{26}$ (Space constraints prohibit detailed discussion of the Lehman case, as also of such places as Cyprus, Iceland and Ireland. Banking systems in these small nations lost substantial sums relative to national output and became insolvent, but the figures were minor in an international context. Chapter 4 discusses Ireland's problems in more detail, on pp. 121-3.)

\section{II}

The time has come to set out the monetary interpretation of the Great Recession. A virtue of this interpretation is that it appeals to a recognized theory of national income determination. This theory has both a well 
understood equilibrium condition and a clear account of how equilibrium is restored when it has been disturbed. The equilibrium condition has been stated in several ways in the textbooks, but the core idea is that the demand to hold money balances is equal to the actual quantity of money created by the banking system at one and only one value of national income. In that sense the equilibrium value of national income is determined by the quantity of money. Keynes in The General Theory was among many authorities who endorsed this idea. ${ }^{27}$

The process of re-equilibrating an economy subject to a monetary shock (such as a sudden and unexpected change in the quantity of money or in the rate of money growth) has also been discussed many times in a large body of literature. The main themes of all such statements are that

- agents have a well-defined money demand function in which national income and a handful of other variables are the key arguments; and

- the money demand function has the property that, for any given set of values of the "other variables", agents have a constant desired ratio of money to income. ${ }^{28}$

If the rate of money growth shifts abruptly in a short period from an established equilibrium, agents have "too much" or "too little" money relative to the level implied by this desired ratio. If money growth has risen and agents have too much money, each agent seeks to pass on part of his or her money holding to another agent by spending above income. But attempted transactions on these lines cannot change the aggregate quantity of money. The money once held by buyers does not disappear from the economy, but must end up in the hands of the sellers. In a wellknown statement from Milton Friedman, "If individuals as a whole were to try to reduce the number of dollars they held, they could not all do so ... [T] hey would simply be playing a game of musical chairs." The excess supply of money is extinguished not by a change in the quantity of money, but by a rise in sales or prices, that is, by higher national income. To quote Friedman again, while individuals in the aggregate may be "[f]rustrated in their attempt to reduce the number of dollars they hold [if they all have an excess supply of money], they succeed in achieving an equivalent change in their position, for the rise in money incomes and prices reduces the ratio of these balances to their income... This process will continue until this ratio ... [is] in accord with their desires". ${ }^{29}$

The chain of events described by Friedman is sometimes known as "the hot potato argument". It evokes the circulation of unwanted money between agents, like that of a disagreeably hot potato, until a new equilibrium with higher prices has emerged and everyone can cool down. The 
hot potato argument is usually applied to markets in goods and services. It has the purpose of demonstrating how, after an unexpected acceleration in money growth, people and companies react when "too much is chasing too few goods". However, the idea is equally applicable to asset markets. ${ }^{30}$ Wealth-holders must at all times balance their money holdings against non-money assets. Given certain characteristics of money and non-money assets (notably their relative rates of return), wealth-holders have a desired ratio of money to non-money assets, including such assets as corporate equity and real estate. Logically, a monetary theory of the determination of national wealth determination must be an associate of the monetary theory of national income determination, since all assets can be viewed as the capitalizations of income streams. Excess money can drive asset price surges, as investors try to rid themselves of the unwanted hot potato of superfluous cash. A situation can arise in which "too much money is chasing too few assets".

How is the notion of a monetary theory of wealth determination to be harnessed in an analysis of the Great Recession? Money balances are held by a range of agents for different motives. Much of the household sector's money is used for immediate transactions needs, and relatively few individuals are balancing money against substantial portfolios of non-money assets in their own names. ${ }^{31}$ Nowadays a high proportion of a society's risk assets are managed by specialist intermediaries, such as mutual funds, pension funds and life insurance companies. Virtually all of these intermediaries' money holdings are run as the most liquid component of larger portfolios dominated by equities, real estate and bonds. Valuable insights into asset price determination might come from monitoring their money balances. $^{32}$

In 2006 the author carried out a data collecting exercise with the USA's flow-of-funds data in order to consider the relationship between savings institutions' money holdings and their total assets. The exercise covered five types of institution (private pension funds, state and local government's employee retirement funds, life-insurance companies, propertyand-casualty insurance companies, and mutual funds) and used data going back to the first quarter of 1952 and ending in the fourth quarter of 2005 . The money holdings and total assets of the five types of institution were added together on a quarterly basis, and then compared. In the 54-year period the total assets of the USA's five main kinds of long-term savings institution increased by 187.1 times at a compound annual rate of 10.2 per cent, while their money holdings rose by 214.2 times at a compound annual rate of 10.5 per cent. Alternatively put, both total assets and money balances increased over this period of more than half a century by about 200 times, but the ratio between the two variables (which is akin to the notion 
Table 1.1 Money and asset holdings of large US savings institutions, 2000-2013 (comparing \% changes in year to fourth quarter)

\begin{tabular}{lccc}
\hline & \multicolumn{3}{c}{ Value of: } \\
\cline { 2 - 4 } & $\begin{array}{c}\text { Total assets held } \\
\text { by large US } \\
\text { savings } \\
\text { institutions }\end{array}$ & $\begin{array}{c}\text { Money holdings } \\
\text { of large US } \\
\text { savings } \\
\text { institutions }\end{array}$ & $\begin{array}{c}\text { Quantity of } \\
\text { money, as } \\
\text { measured by } \\
\text { M3 aggregate }\end{array}$ \\
\hline 2000 & 1.1 & 0.6 & 8.6 \\
2001 & -0.9 & -10.4 & 12.9 \\
2002 & -1.9 & 8.5 & 6.6 \\
2003 & 16.1 & 8.2 & 3.6 \\
2004 & 12.3 & 3.9 & 6.3 \\
2005 & 8.2 & 1.9 & 7.6 \\
2006 & 10.4 & 15.7 & 10.6 \\
2007 & 7.0 & 7.2 & 14.9 \\
2008 & -15.0 & 3.8 & 8.9 \\
2009 & 13.7 & -3.8 & 0.4 \\
2010 & 10.4 & -4.5 & -3.1 \\
2011 & 1.6 & -0.9 & 3.2 \\
2012 & 9.6 & 30.1 & 4.4 \\
2013 & 10.5 & 7.0 & 4.0 \\
- 2000 Q1 to 2013 Q3 & & & 6.4 \\
Average \% annual change & 5.9 & 4.8 & 6.3 \\
Compound \% annual & 5.4 & 4.7 & \\
change & & & 4.5 \\
- 2007 Q1 to 2013 Q3 & & 5.6 & \\
Average \% annual change & 5.4 & & \\
Compound \% annual & 4.8 & & \\
change & & & \\
\hline
\end{tabular}

Source: Federal Reserve flow-of-funds data and M3 until 2006, Shadow Government Statistics for M3 numbers after 2006.

of a "velocity of circulation") changed by just under 15 per cent (that is, at a compound annual rate of about a quarter of a per cent). ${ }^{33}$

The citing of numbers does not establish a definite causal link or prove a rigorous theory beyond contradiction. ${ }^{34}$ But the data are surely suggestive. They argue that a better understanding of the Great Recession may be achieved if the figures are updated to the end of 2013. Table 1.1 shows the changes in the year to the fourth quarter in the quantity of money (as measured by M3), and the long-term savings institutions' 
total assets and money holdings, going back to 2000. On a year-by-year basis, these variables can diverge widely. However, over the medium term they are similar. The numbers could be construed as supporting two hypotheses, that:

- first, confidence (or "animal spirits") may be relevant to asset price determination over short-run periods of a few quarters, associated with noticeable changes in the ratio of savings institutions' money to total assets; but

- second, money dominates the determination of nominal asset prices in the medium and long runs, since over periods of several years or more, changes in the ratio of savings institutions' money to total assets are small compared to changes in the level of either institutions' total assets or their money holdings.

The wider implication of the evidence is that large fluctuations in the growth rate of aggregate money are likely to be accompanied by similarly large fluctuations in the growth rate of money held by the specialist fund management sector. With the fund management industry keeping the ratio of money to total assets fairly stable over the medium term, transactions between different institutional investors (as well as transactions by other investors) cause swings in the rate of money growth to be matched by comparable movements in asset prices.

While the USA's long-term savings institutions are key participants in the markets for quoted corporate equity and bonds, they are far less important as investors in residential real estate. A notorious feature of the years before and during the Great Recession was a pronounced boom and bust in house prices. Is it not a drawback of the present emphasis on the specialist fund management sector that it says little or nothing about the US housing market? The answer is that a capitalist economy has a range of mechanisms by which arbitrage between different asset markets prevents prices and yields in one asset class moving out of line with prices and yields in another. A rich individual can deploy his wealth in rented housing or in his own portfolio of common stocks or in a mutual fund or in a private equity vehicle, and he has constantly to compare their prospects. If an acceleration in aggregate money growth is accompanied in the first instance by massive inflows into the fund management industry and consequent buoyancy in quoted stocks, wealthholders notice the risk of an over-valued stock market. They may divert funds to the purchase of houses for rent or to a fund concentrating on foreign assets or to another vehicle involved in an entirely different asset class. 
Milton Friedman and Anna Schwartz co-authored an article on 'Money and business cycles' in the Review of Economics and Statistics in 1963, at about the same time that their classic A Monetary History of the United States was published. After a survey of the facts about the cyclical behaviour of money from 1867 to 1960, they offered a "tentative sketch of the mechanism transmitting monetary changes" to the economy as a whole. In this sketch an unexpected rise in the rate of growth of the quantity of money was conjectured to disturb "an Elysian state of moving equilibrium, in which real income per capita, the stock of money and the price level" were "changing at the same constant annual rates". In the first round "holders of redundant balances" were seen as acquiring "fixed-interest coupon, low-risk obligations", bidding up their prices. Later money holders would "look further afield" to "higher-risk fixed-coupon obligations, equities, real property, and so forth". Over time the "initially redundant money balances" would "spread throughout the economy".

In understanding the actual pattern of events, Friedman and Schwartz noted that, "it is necessary to take a . . . broader view, to regard the relevant portfolios as containing a much wider range of assets, including not only government and private fixed-interest and equity securities, ... but also a host of other assets, even going so far as to include consumer durable goods, consumer inventories of clothing and the like". ${ }^{35}$ So the hot potato of excess money circulates from one asset market to another, and from asset markets to markets in goods and services. In short, arbitrage between apparently remote asset classes was a basic feature of Friedman and Schwartz's vision of "how the economy really works". In this vision - clearly different from that of Akerlof and Shiller in their 2009 book - asset markets were not an undignified playground for animal spirits. Instead asset prices were recognized as being potentially volatile both upwards and downwards, but still as being determined by explicit economic forces. Highly variable asset prices were seen as being subject to heavy influence from the quantity of that asset which is defined by the fixity of its nominal value, that is, from the quantity of money. (In Chapter 10 Laidler mentions the "tentative sketch" as an important intellectual associate of Friedman and Schwartz's Monetary History, and they were indeed published in the same year, 1963. See p. 23. In Chapter 8 Booth also discusses the role of money in asset price determination on pp. 190-94.)

In early 2006 the Federal Reserve stopped publishing data for the M3 aggregate, on the grounds that the costs of collecting the data for this concept of money were excessive relative to its usefulness in analysing the economy. In 2006 and early 2007 the rate of M3 growth accelerated markedly, so that by early 2008 the annual rate of increase had climbed to 


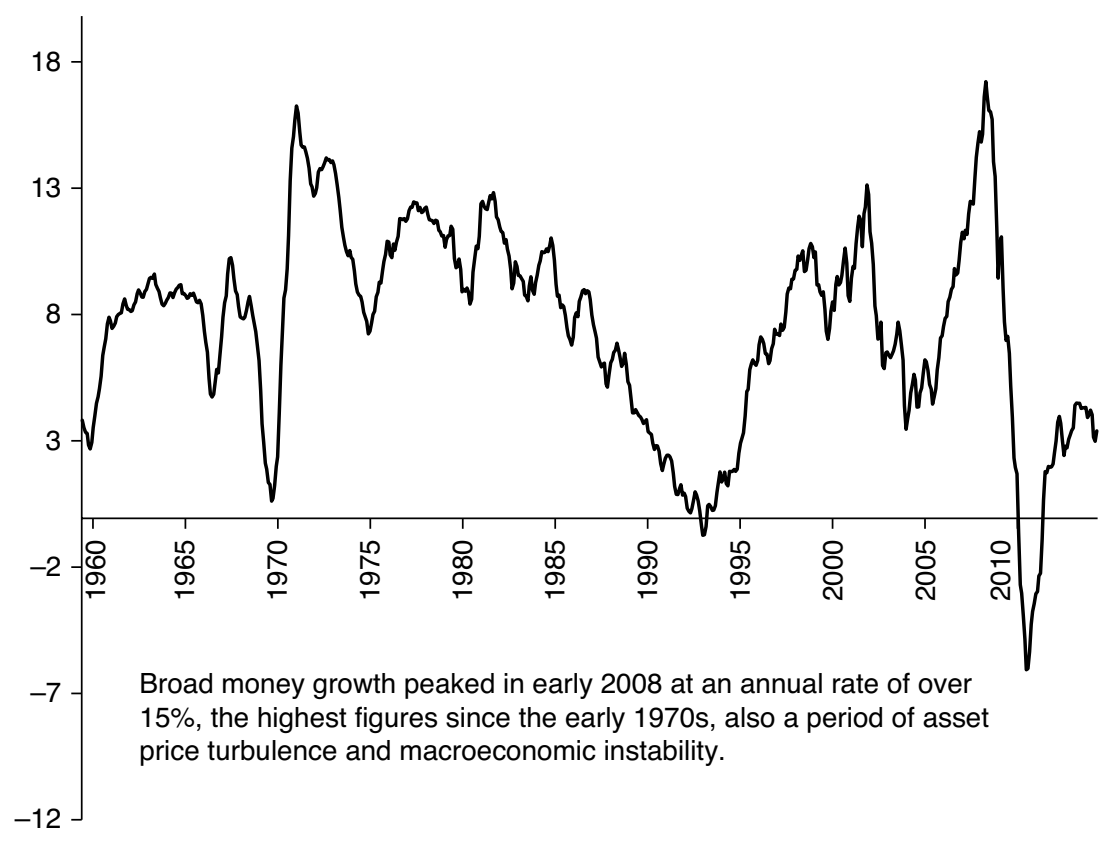

Source: For data sources, see text.

Figure 1.5 Money growth in the USA, 1960-2014 (\% annual rate of change, in M3 aggregate, monthly data)

over 15 per cent. (See Figure 1.5. The M3 aggregate is chosen because the above account of the role of money in the economy emphasizes the need to rationalize the holding of money in portfolios. It is difficult to see how any aggregate smaller than an all-inclusive one could make sense in this setting. The author discussed the relative merits of different money aggregates in his 2011 book Money in a Free Society. ${ }^{36}$ After the Federal Reserve ended the publication of M3, the research company, Shadow Government Statistics, began estimating M3 from publicly available information on its components. The series prepared by Shadow Government Statistics is used in this chapter. It can be cross-checked against the M3 numbers for the USA published by the International Monetary Fund, on data that are still supplied to the IMF by official US sources.)

The broad money growth rates of the 18 months to early 2008 were the highest since the early 1970s, as shown in Figure 1.5. The surge in money growth was accompanied by a proliferation of intermediation via financial organizations, which were quasi-banks or subsidiaries of bank holding 
companies. These were often highly leveraged in the fashion deplored by Greenspan and others, and relied on wholesale funding rather than retail deposits to finance their assets. ${ }^{37} \mathrm{~A}$ similar efflorescence of financial intermediation was also found in the Eurozone and the UK, and again it was associated with fast growth of broad money and financial market excesses. On this view, the asset price excesses and demand buoyancy of 2006 and 2007 were due to too rapid growth of the quantity of money. ${ }^{38}$

Central banks, including the Federal Reserve in the USA, could and should have restrained that boom. They had this responsibility, even if private-sector financiers took many unwise decisions. Of course some banks were foolish to pursue expansionist strategies while the boom gathered pace. As later events showed, the collateral on their loans proved vulnerable in the downturn and a proportion of their loan portfolios became non-performing or worse. But the commercial banking system as a whole was robust. Sure enough, in 2008 and 2009 the hodgepodge of shadow banks and much of the investment banking industry were embarrassed by the collapse in US house prices and the losses in mortgage-backed securities. But only part of their liabilities was of a monetary nature. ${ }^{39}$ If their operations are viewed as important because of feedbacks to the commercial banks as such and because commercial banks' deposits are part of the quantity of money, the troubles of the investment banks and the shadow banks do indeed need to be integrated in the story. However, a valid argument for not overplaying their role in the Great Recession is that their losses were for the most part visited on shareholders and bondholders, not on the banks which had lent to them or (in the important case of the money market mutual funds) on the holders of the funds.

From a monetary perspective the banking industry received two major shocks in the key period of about 18 months from August 2007. The first shock was, as already noted, the freezing of inter-bank credit in August 2007. For some years many banks and quasi-banks, and in the USA the investment banks and shadow banks, had used the inter-bank market to fund asset expansion. The closure of the inter-bank market meant that these organizations would be unable to grow as rapidly as before, and that in turn implied a slowdown in money growth from the rates seen in the previous two years. Nevertheless, even in spring 2008 the slowdown in money growth was not exceptional by past standards in most countries and did not signal severe macroeconomic breakdown. (The UK was an exception and did experience a marked money deceleration, following the Northern Rock imbroglio. See pp. 170-73, in Chapter 7 below, for more on Northern Rock's problems.) The freezing of the global inter-bank market may have been due to mutual distrust within the banking industry, but central banks and regulators in the main economies ought to have known enough about 
banks' assets to recognize that the industry was solvent. The crisis arose because some banks (and investment banks and shadow banks) had difficulty in funding their assets; it was principally a crisis of illiquidity.

The second shock came in September and October 2008, in the weeks following the Lehman default. Arguably, the key event was on 10 October, when G7 finance ministers and central bank governors met in Washington. According to Bernanke in lectures on The Federal Reserve and the Financial Crisis, most such meetings are "a terrible bore because much of the work is done in advance by the staff". But on this occasion, the people present "tore up the agenda" and agreed "a statement of principles written from scratch, based on some Fed proposals". The aim was "to make sure that banks and other financial institutions had access to funding from central banks and capital from governments", and to organize international cooperation "to normalize credit markets" ${ }^{40}$ Other meetings followed in the next few weeks, notably that of G20 heads of state on 14 November in Washington, with the key items on the agenda being mandatory increases in banks' capital and in their capital/asset ratios, and requirements that banks hold a higher proportion of liquid assets to total assets and reduce their dependence on wholesale funding. The emergency conditions were seen by many as justifying an exceptional response, with policy-makers entitled to override convention, precedent and the interests of banks' shareholders. On 21 November President Obama's chief of state, Rahm Emanuel, proclaimed at a Wall Street Journal press conference that, "You never let a serious crisis go to waste. And what I mean by that it's an opportunity to do things you think you could not do before." By early 2009 the Bank for International Settlements in Basel was well advanced in developing a new and drastically more stringent capital regime for the banking industry.

The accepted narrative is unequivocal. Officialdom and academe agreed, with hardly any exceptions, that extra bank capital was the answer to the crisis the banking industry had been facing since August 2007. However, from a monetary control standpoint, the demands for higher capital/ asset ratios were disastrous. Bernanke's notion of capital coming "from governments" raised issues about shareholder property rights, contributing to marked weakness in bank share prices. Further, to the extent that banks were recapitalized from private sources, the result was to destroy bank deposits. ${ }^{41}$ (An investor purchases new stock only by making a payment from a deposit. The claim on the banking system takes the non-monetary form of equity or bonds, instead of the monetary form of a deposit.) The increases in capital/asset ratios were also catastrophic in their immediate effects on both credit availability and the quantity of money. The collapse in banks' share prices reduced their access to capital markets. They were 
therefore unable to obtain the extra capital needed to sustain balance-sheet expansion. At best banks had to stop growing their assets. In many cases they took active steps to shrink balance sheets. They sold off securities and loan portfolios, and sometimes even called in loans. (If securities are sold to non-banks, non-banks must pay for them from deposits, which disappear from the economy. When a loan is repaid by cancelling a deposit, the effect is again to destroy money.)

In most of the leading advanced economies the rate of money growth, which had run at a double-digit annual rate in 2006 and 2007, crashed to negligible levels. In both the USA and the Eurozone the annual rates of change were for some months at zero or less. (See the Appendix for more detail.) The zero rate of money growth was bad enough, but money could have contracted - for the first time since the 1930s - if central banks had not engaged in expansionary asset purchase operations, including the "quantitative easing" schemes of the USA and the UK. Households were reluctant to cut back on their money holdings, perhaps for precautionary reasons.$^{42}$ The zero rate of aggregate money growth therefore led to severe cash strains for economies' other money holders, including many companies and financial institutions. ${ }^{43}$ This squeeze on money balances was accompanied by drops in asset prices and by consequent adverse "wealth effects" on expenditure, as already remarked in the discussion of the relationship between money and asset prices. The processes at work recalled the "tentative sketch" advanced by Friedman and Schwartz in 1963, but they operated in reverse, as the quantity of money was being squeezed rather than expanded.

The narrative of events in the 2008-10 period was not identical to that in previous deep recessions, but obvious similarities suggested a common pattern of causation. For all their idiosyncrasies, data on the quantity of money go back decades and are amenable to rigorous statistical analysis. Indeed, a monetary interpretation of the Great Recession echoes in many of its features the monetary interpretation of the Great Depression advanced by Milton Friedman and Anna Schwartz in their celebrated 1963 volume A Monetary History of the USA, 1867-1960. For most of the 1920s the USA's money stock increased by about 5 per cent a year; between 1929 and 1933 it plummeted by almost 10 per cent a year and, over the whole four-year period, it fell by more than a third. The asset price tumbles in the Great Recession were less bad than in the Great Depression (when the US stock market dropped by over 90 per cent from peak to trough). Nevertheless, in both episodes a sharp change in the rate of increase in the quantity of money had damaging effects on the stock market and real estate. It should also be noted that the instability in money growth in the 2006-10 period was the most extreme since the early 1970s, which were also 
accompanied by macroeconomic upheaval, and large movements in asset prices and inflation rates. ${ }^{44}$

The monetary approach to the Great Recession not only interprets events from a theoretical standpoint at variance with the mainstream approach, but also allocates blame in different ways. In brief, the monetary interpretation

- sees bank illiquidity, not insolvency, as the main weakness of the financial system in the crisis period;

- it condemns officialdom for the drastic and hurried tightening of bank regulation from October 2008, as this tightening was the dominant influence on the collapse in money growth which in turn was responsible for the severity of the global downturn in the following two or three quarters; and

- it applauds central bank action to boost the quantity of money (usually termed "quantitative easing") from spring 2009, since without QE the regulatory tightening would have resulted in an even more vicious macroeconomic slump.

\section{III}

The standard and monetary interpretations of the Great Recession have the same cast of characters (central bankers, regulators, commercial bankers and so on) and same stage props (institutions like central banks and regulatory agencies). But the interpretations can be seen as rival whodunits, and they have different scripts and identify different culprits. In the standard interpretation the villains are bankers, because they ran - or are alleged to have run - their businesses irresponsibly in the run-up to the crisis, and so risked insolvency. In the monetary interpretation much of the blame instead attaches to central bankers and regulators, and in particular to those members of officialdom and the commentariat who urged rapid bank recapitalization in late 2008. According to the monetary school, the threat to the system then was illiquidity, not insolvency. Prompt, largescale action both to fund the banking system (by means of central bank loans to commercial banks) and to boost the quantity of money was vital. Such action would have prevented the Great Recession. Banks should have been given time to recapitalize, so that money growth would decelerate only gradually from the highs of 2006 and 2007. Alternatively, bank recapitalization should have been accompanied immediately by QE-type operations to boost the quantity of money. It was the abrupt bank recapitalizations and step jumps in regulatory capital/asset ratios that caused the money growth collapse and macroeconomic trauma of early 2009. 
The debate between the standard and monetary interpretations of the Great Recession is basic both to the future of the international financial system and to the proper definition of the state's role in a modern economy. So far the mainstream approach has been very much in the ascendant, with the Lo review article in the 2012 Journal of Economic Literature containing not a single reference to a monetary aggregate. More analysis and other reviews of the evidence will be needed before the debate is settled. This chapter, and those that follow, argue that the monetary interpretation has to be taken far more seriously than has been the case until now.

\section{NOTES}

* This chapter is a modified version of the paper which first appeared in World Economics (June 2014) and is reproduced with permission.

1. A book-length contribution from the monetary side of the debate is Robert Hetzel The Great Recession: Market Failure or Policy Failure? (Cambridge: Cambridge University Press, 2012).

2. Andrew W. Lo 'Reading about the financial crisis: a twenty-one book review', Journal of Economic Literature, 2012, vol. 50, no. 1, pp. 151-78. The quotations are from p. 153 and p. 155.

3. A virtually unanimous theme has been that the answer must include tighter financial regulation, as, for example, elaborated in Chapter 3 (pp. 57-120) of Joseph E. Stiglitz The Stiglitz Report (New York and London: The New Press, 2010).

4. George A. Akerlof and Robert J. Shiller Animal Spirits (Princeton, NJ, USA and Oxford, UK: Princeton University Press, 2009), p. xi.

5. Alan Greenspan The Map and the Territory (London: Allen Lane for Penguin Books, 2013), p. 53 and p. 71.

6. Akerlof and Shiller Animal Spirits, p. 131.

7. See, for example, pp. 120-27 of Johan Lybeck A Global History of the Financial Crash of 2007-10 (Cambridge: Cambridge University Press, 2011) for a discussion of the effect of house prices and debt on overall household wealth.

8. Debt, any kind of debt, is sometimes seen as morally repugnant. "Debt is a means of unfairly living high on the hog today only to pay a bigger bill tomorrow," while "When capitalism is unfair, we have financial crashes." The quotations are from p. 183 and p. 189 of Will Hutton 'The financial crisis and the end of the hunter-gatherer', pp. 182-9, in Rowan Williams and Larry Elliott (eds) Crisis and Recovery: Ethics, Economics and Justice (Basingstoke: Palgrave Macmillan, 2010).

9. Greenspan The Map and the Territory, p. 115, on the investment banks.

10. See also Joseph E. Stiglitz Freefall: Free Markets and the Sinking of the Global Economy (London: Allen Lane for Penguin Books, 2010), p. 163, for his views on investment bank leverage. But Stiglitz often mentioned "excessive risk-taking" in the context of "banks" in general, inviting the interpretation that the commercial banks as well as the investment banks had over-geared their balance sheets.

11. Bernanke seems to have had second thoughts about the "special-ness" of banks in his speech on 'The financial accelerator and the credit channel' to a conference on the credit channel held by the Federal Reserve Bank of Atlanta on 15 June 2007, where he described the notion as "rather dated".

12. The key reference is R. Clarida, J. Gali and M. Gertler 'The science of monetary policy: a New Keynesian perspective', Journal of Economic Literature, 1999, vol. 37, no. 2, 
pp. 1661-707. The neglect of banks in New Keynesianism has been widely noted and criticized. See, for example, Laidler's comments on pp. 247-8 below.

13. Paul Krugman 'Gordon Does Good', 12 October 2008, column in New York Times. According to Krugman, ". . . we do know ... that Mr. Brown and Alistair Darling ... have defined the character of the worldwide rescue effort, with other wealthy nations playing catch-up."

14. Alan S. Blinder After the Music Stopped (New York: The Penguin Press, 2013), p. 271.

15. Even authors usually regarded as supporters of free markets have attacked the financial system. See, for example, Kevin Down Alchemists of Loss (Chichester: John Wiley \& Sons, 2010).

16. Akerlof and Shiller Animal Spirits, pp. 14-17.

17. Loan loss write-offs as a percentage of total assets were unusually adverse in the Great Recession, notably for residential mortgage loans, but they did not reach such high levels as to wipe out banks' operating profits. According to an analysis conducted by the Federal Reserve's research staff, the net interest income of the US commercial banking system in 2009 was 3.02 per cent of assets, and non-interest income 2.07 per cent of assets, both figures not that different from the immediately preceding years. Unhappily, loss provisions ran at 1.95 per cent of assets in 2009, up from only 0.27 per cent in 2006 . But even in 2009, which was the worst year in the Great Recession, the US banking system as a whole had a positive return on equity. See 'Profits and balance sheet developments at US commercial banks in 2009', Federal Reserve Bulletin (Washington, DC: Federal Reserve), May 2010 issue, pp. A1-A37, and in particular p. A28 and p. A37 for the overall profitability of the system.

18. In 2009 and 2010 many banks had loan write-offs that were similar to operating profits, although their capital was intact or even rose because they raised new capital. See Lybeck $A$ Global History, pp. 160-62.

19. "By the early 1980s many banks including the largest were recording capital ratios of 5 per cent or less." Brian Kettell and George Magnus The International Debt Game (London: Graham \& Trotman, 1986), p.9. The author discussed the debt crisis of the 1980s in a popular book, The Debt Threat (Oxford: Basil Blackwell, 1988). He noted the fragility of banks with a 3.6 per cent equity to assets ratio on p. 176 of The Debt Threat, as part of a wider review of "the leveraging of America".

20. A guide to the vulnerability of the whole system to losses in particular banks (i.e., because of a wide dispersion of profit and loss outcomes between industry players) is provided by the experience of the Federal Deposit Insurance Corporation. The FDIC did incur significant "losses", in the sense that it had to set out provisions for prospective shortfalls in banks' deposit liabilities, and these losses did cause the so-called "Fund Balance" (which is a notional figure, since reported losses may in the end not materialize) to be recorded as negative at the end of 2009 to the tune of almost \$21 billion. However, in the three years to end-2012 over $\$ 10$ billion of the provisions turned out to have been unnecessary, and the "Fund Balance" was back to a positive $\$ 33$ billion by end-2012. (The information here is from FDIC annual reports reported on its website.) Note that the \$21 billion negative figure in the end-2009 FDIC's Fund Balance was trivial compared with US commercial banks' total equity capital at the same time, which was over $\$ 1200$ billion.

21. Sheila Bair Bull by the Horns (New York: Free Press, 2012), p. 159. The acknowledgement of the solvency of the system was followed by a complaint about the bias of top American policy-makers to protect the big banks rather than the small.

22. Bair Bull by the Horns, p. 358 .

23. Note on 'Who is the FDIC?' updated on 18 January 2013 and available on FDIC website at 18 March 2014.

24. The Wikipedia entry on the savings and loans crisis is clear and sufficient. It mentions the 1996 General Accounting Office estimate that the total cost of the S\&L clean-up was $\$ 160$ billion, including $\$ 132.1$ billion from taxpayers.

25. The Lehman losses did not fall on the US taxpayer, but on Lehman creditors. In April 
2011 the FDIC published a report on 'The orderly liquidation of Lehman Brothers Holdings under the Dodd-Frank Act', claiming that powers granted to the FDIC by the Dodd-Frank Act would have led to a much higher recovery rate on Lehman liabilities than actually seen in practice. In the paper's view a more orderly procedure under FDIC oversight would have enabled "general unsecured creditors" to achieve 90 cents on every dollar of claims "compared with approximately 20 cents on claims estimated in the most recent bankruptcy plan". The report was available on the FDIC website under the 'Regulations \& Examinations' button at end-March 2014.

26. See George Akerlof 'The cat in the tree and further observations', pp. 317-20, in George Akerlof, Olivier Blanchard, David Romer and Joseph Stiglitz (eds) What Have We Learned? Macroeconomic Policy after the Crisis (Cambridge, MA, USA and London, UK: MIT Press, 2014). The quotation is from p. 319.

27. John Maynard Keynes The General Theory of Employment, Interest and Money, vol. VII in Donald Moggridge and Elizabeth Johnson (eds) Collected Writings of John Maynard Keynes (London and Basingstoke: Macmillan, 1973, originally published 1936), pp. 84-5.

28. This proposition is related to "the homogeneity postulate" that lies at the centre of monetary theory, as explained, for example, by Patinkin in Money, Interest and Prices. (See p. 175 of Don Patinkin Money, Interest and Prices (New York: Harper \& Row, 2nd edition, 1965).)

29. See Milton Friedman 'Statement on monetary theory and policy', given in Congressional hearings in 1959, reprinted in R.J. Ball and Peter Boyle (eds) Inflation (Harmondsworth: Penguin, 1969), pp. 136-45. The quotations are from p. 141.

30. In the current policy literature the processes at work are frequently lumped under the "portfolio rebalancing channel". For an example in real-world policy-making, see Marvin Goodfriend 'Policy debates at the Federal Open Market Committee, 1993-2002', pp. 332-73, in Michael D. Bordo and William Roberds The Origin, History, and Future of the Federal Reserve (Cambridge: Cambridge University Press, 2013), particularly p. 364.

31. In the UK the Bank of England has prepared data on the money holdings of the economy's main sectors (households, companies, financial institutions) since 1963. A clear research finding is that the household sector's money demand function is stable, according to the usual statistical tests. See, for example, Alec Chrystal and Leigh Drake 'Personal sector money demand in the UK', Oxford Economic Papers (Oxford: Oxford University Press), 1997, April issue, vol. 49, no. 2, pp. 188-206.

32. An extreme case could be imagined in which equities are held only by specialist nonbank financial institutions, these institutions hold constant the ratio of money to total assets, and their money holdings grow at the same rate of the aggregate quantity of money. In this extreme case it is obvious that the rate of increase in share prices must be equal to the rate of increase in the aggregate quantity of money.

33. Tim Congdon 'Broad money vs. narrow money: a discussion following the Federal Reserve's decision to discontinue publication of M3 data', London School of Economics' Financial Markets Group Special Paper Series, no. 166. An amended version of this paper appeared as essay 16, pp. 346-73, in Tim Congdon Money in a Free Society (New York: Encounter Books, 2011).

34. Can the same kind of relationships as those discussed in the text also be found in other economies? The author considered the evidence for the UK in his 2005 study on Money and Asset Prices in Boom and Bust for the Institute of Economic Affairs. See Tim Congdon Money and Asset Prices in Boom and Bust (London: Institute of Economic Affairs, 2005) and also essay 15 in Congdon Money in a Free Society, which is a condensed version of the 2005 study.

35. See Milton Friedman and Anna Schwartz 'Money and business cycles', pp. 189-235, in Milton Friedman The Optimum Quantity of Money (London and Basingstoke: Macmillan, 1969). The quotations are from pp. 229-31.

36. See, particularly, essay 16 (pp. 346-73) in Tim Congdon Money in a Free Society (New York: Encounter Books, 2011). 
37. One example of the over-leveraging was the Carlyle Capital Corporation, a highly geared bond fund conceived and marketed by the Carlyle Group, well-regarded specialists in private equity. Launched in November 2006, it borrowed more than 20 times its own equity to invest in highly-rated mortgage paper. It went bust in March 2008. According to a story in the Financial Times of 30 November, 2009 (Henny Sender 'Leverage levels a fatal flaw in Carlyle fund'), "By the end of 2007, CCC had borrowed $\$ 21 \mathrm{bn}$. At the end of the following February, in its annual letter to investors, John Stomber, CCC's chief investment officer referred to the fund's 'decisive action to reduce risk, enhance liquidity and preserve the value of shareholders' capital'. The fund's leverage, $\mathrm{Mr}$ Stomber noted, was 32 times greater than its equity."

38. Some sources mentioned the role of money in the cycle at an early stage. See Charles A.E. Goodhart The Regulatory Response to the Financial Crisis (Cheltenham, UK and Northampton, MA, USA: Edward Elgar Publishing, 2009), p. 10 and p. 52, drawing on papers written in 2008 .

39. Money market mutual funds are part of M3. The fears in 2007 and 2008 that these products would "break the buck" (that is, fail to pay back 100 cents in the dollar) need to be mentioned in a monetary account of the crisis. In this respect it has to be conceded that the emphasis on the commercial banks in the present paper is incomplete.

40. Ben S. Bernanke The Federal Reserve and the Financial Crisis (Princeton, NJ: Princeton University Press, 2013), pp. 74-5.

41. See Jonathan Bridges, Neil Rossiter and Ryland Thomas 'Understanding the recent weakness in broad money growth', pp.22-35, Bank of England Quarterly Bulletin (London: Bank of England), 2011 (Q1), vol. 51, no. 1. Note, particularly, the discussion on pp. $27-8$.

42. If the money balances of one sector of the economy (such as the household sector) are stable, changes in the growth rate of aggregate money are necessarily accompanied by proportionately larger changes in growth rate of money held by other sectors (such as companies and financial institutions). The point was emphasized by the author in Chapter 2 of his study Money and Asset Prices in Boom and Bust (London: Institute of Economic Affairs, 2005), see particularly pp. 32-7.

43. As noted in note 31 above, UK data on the main sector's money holdings have been published since 1963. A recurrent feature of UK business cycles has been markedly higher volatility in the money holdings of financial institutions than of the household sector, as noted in the author's 2005 Money and Asset Prices in Boom and Bust. This was again seen in the Great Recession. In the 10 quarters to the final quarter of 2007 the average annual growth rate of money in the hands of financial institutions (excluding so-called "intermediate other financial corporations" or quasi-banks) was 16.6 per cent; in the 12 quarters to the final quarter of 2011 it was 0.5 per cent. (Data are from the Bank of England's interactive statistical database, using series mnemonic RPQB66Q, as at endMarch 2014.)

44. The marked instability in money growth in both the early 1970s and the Great Recession was noted in Congdon Money in a Free Society, pp. 384-7. 


\section{APPENDIX: BROAD MONEY GROWTH TRENDS IN THE MAJOR ADVANCED COUNTRY JURISDICTIONS, 2000-2013}

The purpose of this Appendix is to review the monetary experience of the major advanced country jurisdictions (the USA, the Eurozone, Japan and the UK) in the years before, during and after the Great Recession. The M3 broad money measure is used, except for the UK where the M4x measure is preferred. (The M4x measure excludes money held by so-called "intermediate other financial corporations", on the grounds that such balances are those of bank affiliates or semi-banks, and should be kept out of money estimates for the same reason that these exclude inter-bank deposits.)

The USA is covered first. The graph shows a fair degree of stability in money growth in the years before the financial excesses and boom of 2006 and 2007, and the subsequent macroeconomic trauma. In 2004 and 2005 the average annual growth of M3 was 5.5 per cent, with little variation. However, in 2006 a pronounced acceleration in money growth emerged. The 18 months to the first quarter of 2008 saw extremely fast expansion of bank deposits, although a proportion of the increase may have been due to re-intermediation of financial business from shadow banks and related institutions, particularly in late 2007. The peak in the three-month annualized growth rate of M3 was recorded in October 2007, coinciding with a stock market high. From early 2008 money growth collapsed, with the three-month annualized rate of change dropping to 3 per cent in November 2008 and going negative in late 2009. A fair comment is that US broad money did not lead the economy in the Great Recession period, since late 2009 was a period of stock market recovery and a strongly positive contribution to demand from the inventory cycle. However, the compound annual growth rate of M3 in the three years from September 2008 was only just positive, at 0.2 per cent, whereas in the three years to September 2008 it had been 12.6 per cent. The shrinkage of the American banking system was such that the quantity of money actually declined in the year to mid-2010, for the first time over a significant period since the 1930s. The USA was characterized by a boom-bust pattern in money growth in the Great Recession period, in association with the boom and bust in demand and output.

The message of the data for the Eurozone is clearer than that for the USA. M3 growth was again moderate in 2004, with an average annual growth rate of 5.8 per cent. The acceleration to double-digit annual growth rates started earlier than in the USA, with late 2005 and 2006 being characterized by extraordinarily high annual money growth rates (often into the twenties per cent) in some of the peripheral countries, such as Ireland. In 




Sources: For sources, see text.

Figure 1A.1 Growth of broad money (M3) in the USA 2000-2013 (monthly data, \% changes)

these nations very high money growth occurred in tandem with wild real estate booms. The three-month annualized rate of change of Eurozone M3 just touched the low teens in 2007, with a peak in November of 13.8 per cent. Figure 1A.2 shows the first marked deceleration from that rate, to a figure in the mid-single digits, by autumn 2008. The tightening of bank regulation was then announced in the closing months of 2008, bringing money growth to a halt. By late 2009 the annual rate of change went negative. The Eurozone therefore also underwent a marked and obvious boom-bust phenomenon in money growth, and it is relatively straightforward to relate that boom-bust phenomenon to other macroeconomic developments. The compound annual growth rate of M3 in the three years 
from September 2008 was a positive 0.3 per cent, whereas in the three years to September 2008 it had been 10.5 per cent.

The UK enjoyed monetary stability in a period of almost 15 years from its exit from the European exchange rate mechanism in 1992, with broad money growth typically somewhat above 5 per cent a year, which was consistent with steady growth in nominal GDP at about 5 per cent a year as agents were prepared to increase the ratio of their money holdings to income. However, in 2005 and particularly in 2006 money growth accelerated, with the three-month annualized growth rate topping out at 12.6 per cent in autumn 2006 (see Figure 1A.3). Strong gains in house prices and the stock market accompanied the high money growth. The Northern Rock affair from September 2007 led to a deceleration in money growth, earlier than in other countries. In the third quarter of 2008 the banking system had virtually stopped growing, with the three-month annualized rate of increase in M4x down to 2.6 per cent. The tightening of bank regulation in late 2008 was followed by a further slowdown and in early 2010

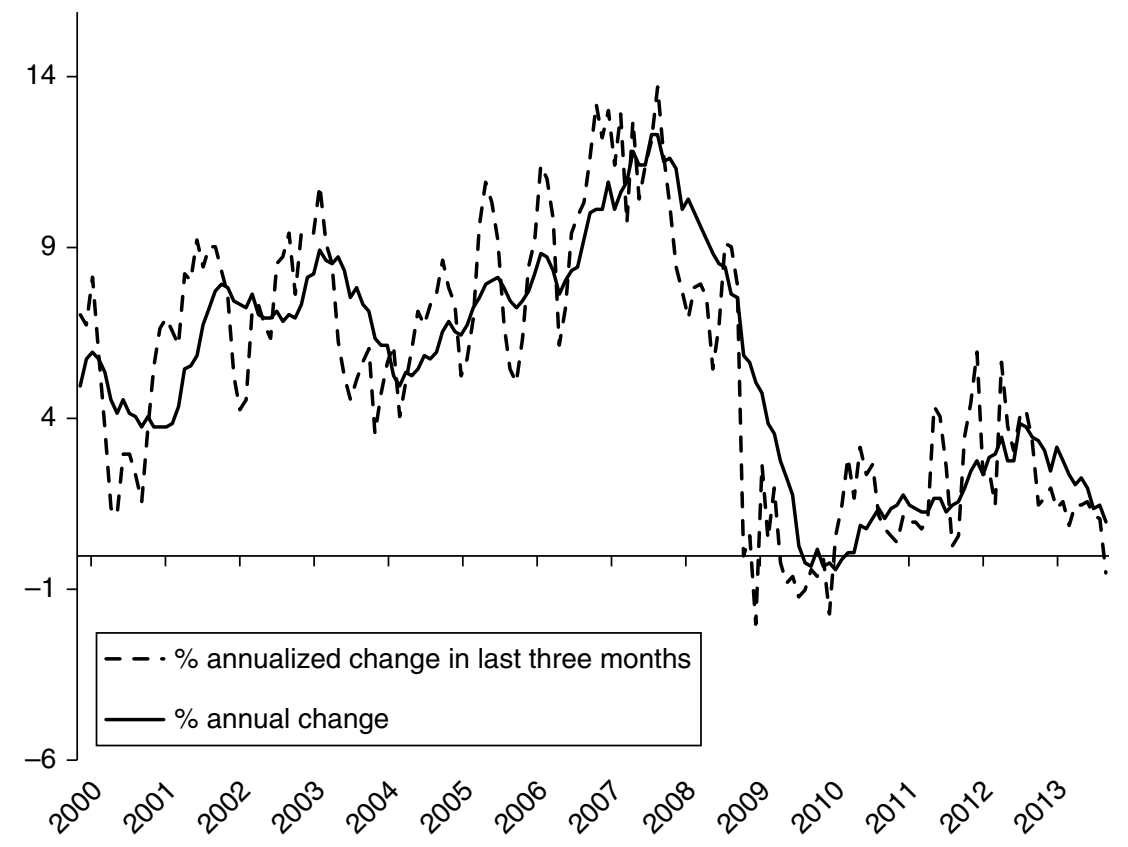

Source: ECB.

Figure 1A.2 Growth of broad money (M3) in the Eurozone 2000-2013 (monthly data, \% changes) 
the annual increase in $\mathrm{M} 4 \mathrm{x}$ was a mere 1 per cent. The compound annual growth rate of M3 in the three years from the first quarter of 2008 was 1.1 per cent, whereas in the three preceding years it had been 9.1 per cent.

The USA, the Eurozone and the UK had different macroeconomic trajectories in the Great Recession, and in the years immediately before and afterwards. Nevertheless, in every case broad money growth was at or near double-digit annual rates in the three years before the banking system began to retrench, and close to zero in the following three years. As noted in the opening paragraph of the main text, Japan does not fit this pattern. It had very weak money growth in the years leading up to the Great Recession, with a trough in 2006 (see Figure 1A.4). Money growth recovered from 2009 , to be typically about 2 or 3 per cent a year. Japan nevertheless suffered severely in the Great Recession, with a decline in GDP in 2009 of over 5 per cent. The main factor here was a slump of about a quarter in the volume of exports of goods and services (offset by a fall of 15 per cent



Source: Bank of England.

Figure 1A.3 Growth of broad money (M4x) in the UK 2000-2013 (quarterly data, \% changes) 


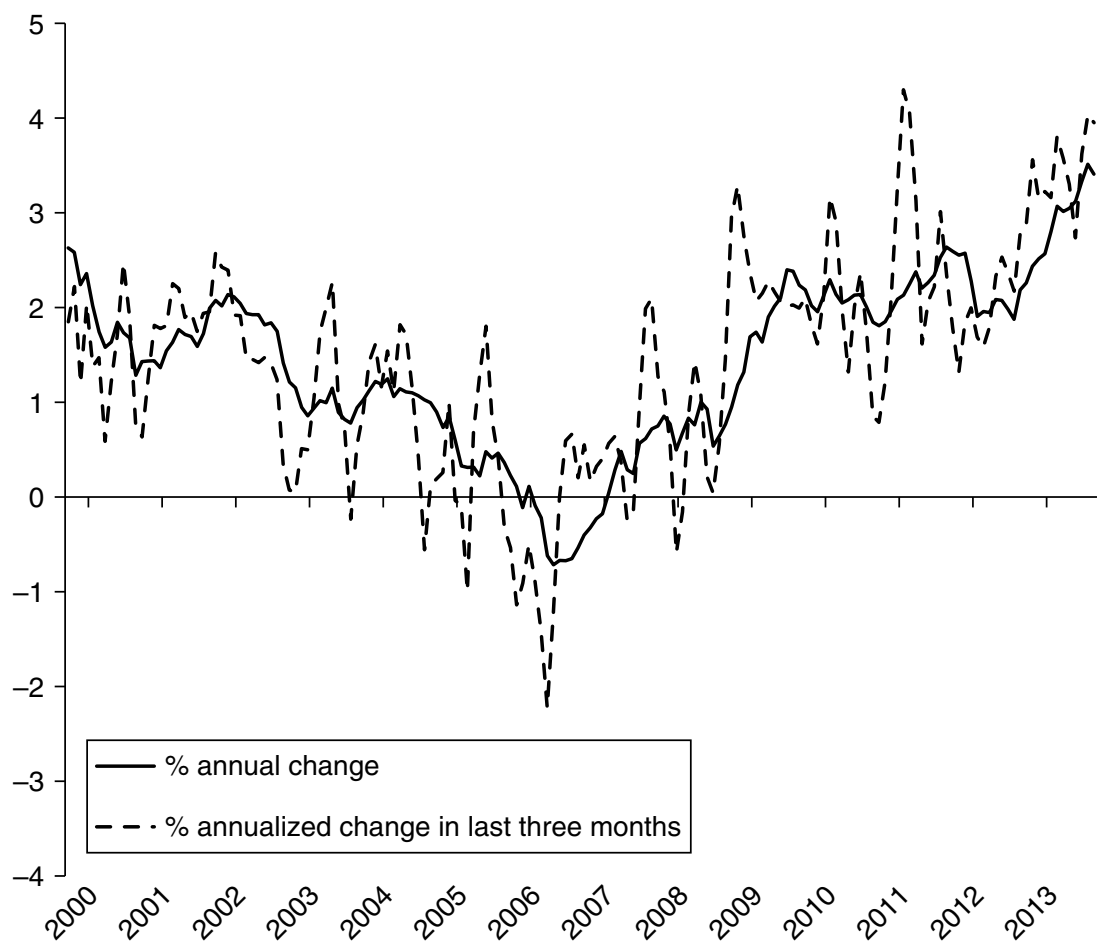

Source: Federal Reserve, using Bank of Japan data.

Figure 1A.4 Growth of broad money (M3) in Japan 2000-2013 (monthly, $\%$ changes)

in imports), which can be interpreted as partly caused by an abrupt real exchange appreciation in late 2008 and early 2009. The rise in the yen reflected the closing of so-called "carry trades" in the foreign exchange markets. In the years up to late 2008 short-term interest rates in other advanced countries had been well above those in Japan, enabling foreign exchange market participants to capture a favourable interest rate differential by shorting the yen. The tightening of bank regulation from October 2008 was such a severe deflationary shock that it had to be countered by interest rate reductions, to a virtually zero rate, in the USA, the Eurozone and the UK. The carry trades were closed, the yen soared against other currencies, and Japanese exports suffered from a lack of competitiveness as well as a collapse in demand due to the Great Recession. 